\title{
ERRATUM
}

\section{Fusion energy using avalanche increased boron reactions for block-ignition by ultrahigh power picosecond laser pulses- ERRATUM}

\author{
HEINRICH HORA, GEORG KORN, LORENZO GIUFFRIDA, DANIELE MARGARONE, \\ ANTONINO PICCIOTTO, JOSEF KRASA, KAREL JUNGWIRTH, JIRI ULLSCHMIED, \\ PARASKEVAS LALOUSIS, SHALOM ELIEZER, GEORGE H. MILEY, STAVROS MOUSTAIZIS, \\ AND GÉRARD MOUROU
}

doi:10.1017/S0263034615000634. Published by Cambridge University Press, 14 July 2015.

During the proofing stage one of the authors' names was not spelled out completely, we are correcting that error below.

HEINRICH HORA, GEORG KORN, LORENZO GIUFFRIDA, DANIELE MARGARONE, ANTONINO PICCIOTTO, JOSEF KRASA, KAREL JUNGWIRTH, JIRI ULLSCHMIED, PARASKEVAS LALOUSIS, SHALOM ELIEZER, GEORGE H. MILEY, STAVROS MOUSTAIZIS, AND GÉRARD MOUROU

\section{ADDENDUM}

The original version of this notice gave the wrong first name of the author ANTONINO PICCIOTTO. This has been corrected above, and the original article has been updated to include this author's full name. We are deeply sorry for both the original error and the compounded mis-spelling in the notice, and apologise to the author.

In addition, the following corrections should also be noted:

Page 2, right column, paragraph 1, line 13 should read "After this breakthrough, the measurement of $\mathbf{1 0}$ / $/ \mathbf{s r}$ reactions (Picciotto et al., 2014; Margarone et al., 2015)"

Page 2, right column, paragraph 4, line 3 should read “... resulted in the generation of $\mathbf{1 0}$ \% $/$ sr HB11 reactions.”

\section{REFERENCE}

Hora, H., Korn, G., Giuffrida, L., Margarone, D., Picciotto, A., Krasa, J., Jungwirth, K., Ullschmied, J., Lalousis, P., Eliezer, S., Miley, G.H., Moustaizis, S. \& Mourou, G. Fusion energy using avalanche increased boron reactions for block-ignition by ultrahigh power picosecond laser pulses. Laser Part. Beams. doi:10.1017/S0263034615000634. Published by Cambridge University Press, 14 July 2015. 